\title{
Varicella zoster virus meningitis with hypoglycorrhachia in the absence of rash in an immunocompetent woman
}

\author{
Ali A Habib ${ }^{1}$, Don Gilden ${ }^{2}$, D Scott Schmid ${ }^{3}$, and Joseph E Safdieh ${ }^{1}$ \\ ${ }^{1}$ Department of Neurology, New York Presbyterian Hospital Weill Cornell Medical College, New \\ York, New York, USA \\ 2 Departments of Neurology and Microbiology, University of Colorado Denver School of Medicine, \\ Aurora, Colorado, USA \\ ${ }^{3}$ National Center for Infectious Diseases, Centers for Disease Control and Prevention, Atlanta, \\ Georgia, USA
}

\begin{abstract}
We report varicella-zoster virus (VZV) meningitis in a healthy adult woman with no antecedent rash and with hypoglycorrhachia. Cerebrospinal fluid (CSF) examination revealed the presence of VZV DNA, anti-VZV immunoglobulin G (IgG) antibody, and intrathecal production of anti-VZV IgG antibody.
\end{abstract}

\section{Keywords}

varicella zoster; meningitis; hypoglycorrhachia; PCR; immunocompetent

\section{Case report}

A 26-year-old healthy Bhutanese woman developed increasing throbbing bitemporal headache with photophobia, severe nausea, and vomiting over 2 days. She had been afebrile and denied neck stiffness. There was no past history of headache, skin rash, recent insect bite, or contact with individuals with infections. She had chickenpox at age 5 years. She had emigrated from Bhutan 7 years earlier, but had not traveled abroad recently. Her sister had been treated for tuberculosis. She worked currently as a nanny; the children under her care were healthy and had received Varivax months earlier. On examination, the patient was afebrile and had no rash, nuchal rigidity, or abnormal neurological signs.

On day 6 after becoming ill, white blood cell (WBC) count and routine blood chemistries, liver enzymes, erythrocyte sedimentation rate (ESR), anti-nuclear antibody, rapid plasma reagin, and human immunodeficiency virus testing were negative. Brain magnetic resonance imaging (MRI) revealed an ill-defined T2 hyperintensity in the right frontal lobe, extending from the cortical surface to the frontal horn of the lateral ventricle without mass effect, consistent with a hamartoma or cortical dysplasia. The cerebrospinal fluid (CSF) contained $331 \mathrm{WBCs}, 99 \%$

\footnotetext{
Address correspondence to Don Gilden, MD, Department of Neurology, Mail Stop B182, University of Colorado Denver School of Medicine, 12700 E. 19th Avenue, Aurora, CO 80045, USA. don.gilden@ucdenver.edu.

Declaration of interest: The authors report no conflicts of interest. The authors alone are responsible for the content and writing of the paper.

The findings and conclusions in this report are those of the authors and do not necessarily represent the views of the Centers for Disease Control \& Prevention.
} 
mononuclear; CSF protein was $219 \mathrm{mg} / \mathrm{dl}$, and there were no oligoclonal bands; CSF glucose was $28 \mathrm{mg} / \mathrm{dl}$ (serum glucose $75 \mathrm{mg} / \mathrm{dl}$ ). She was treated with ceftriaxone, ampicillin, and intravenous acyclovir ( $10 \mathrm{mg} / \mathrm{kg}$ every $8 \mathrm{~h}$ ) as well as rifampin, isoniazid, pyrazinamide, and ethambutol because of her history of tuberculosis exposure. Bacterial and viral cultures using MRC-5 primary monkey kidney and HEp-2 cells, acid fast bacillus smear and culture, and polymerase chain reaction (PCR) for mycobacteria were negative.

By day 8 , her headache and associated symptoms resolved, and the remainder of her hospitalization was uncomplicated. All antibiotics were discontinued after bacterial culture and tuberculosis PCR were negative. A repeat MRI with gadolinium on day 10 was normal, with no change in the solitary $\mathrm{T} 2$ hyperintensity. A repeat CSF examination on day 13 revealed 108 WBCs, all mononuclear; CSF protein at $95 \mathrm{mg} / \mathrm{dl}$ and glucose at $39 \mathrm{mg} / \mathrm{dl}$ (serum glucose $88 \mathrm{mg} / \mathrm{dl}$ ). She completed a 21-day course of intravenous acyclovir. A third CSF examination 1 month after the onset of symptoms did not reveal a pleocytosis; CSF protein was $46 \mathrm{mg} / \mathrm{dl}$ and glucose was $48 \mathrm{mg} / \mathrm{dl}$ (serum glucose $90 \mathrm{mg} / \mathrm{dl}$ ).

\section{Special studies}

On day 6, PCR of the CSF revealed no amplifiable herpes simplex virus (HSV) or cytomegalovirus (CMV) DNA, but was positive for varicella-zoster virus (VZV) DNA (127,000 copies per ml CSF); studies for antiviral antibodies were not performed. On day 13, the CSF was negative for VZV DNA, but did contain anti-VZV IgG antibody. The serum/CSF ratio of anti-VZV immunoglobulin $\mathrm{G}(\mathrm{IgG})$ was 1.0 compared to a ratio of 52 for total $\mathrm{IgG}$ and 31 for albumin, and there was no anti-HSV IgG antibody in CSF, all consistent with intrathecal synthesis of anti-VZV IgG antibody. Because the second CSF did not contain VZV DNA, the third CSF obtained 1 month after onset of illness was not tested for VZV DNA, but was examined for anti-VZV IgG antibody, which was still present.

\section{Discussion}

We describe VZV meningitis in an immunocompetent adult woman with no antecedent zoster rash and with hypoglycorrhachia. Virological verification was provided by the detection of VZV DNA in CSF during acute disease and the detection of anti-VZV IgG antibody and intrathecal production of anti-VZV IgG antibody during convalescence. This report illustrates two notable features. First, it is the first case to show that PCR can detect VZV DNA in CSF during the first week of meningitis, followed by the disappearance of the DNA during the second week when anti-VZV IgG was found in CSF, the same pattern observed for HSV DNA and anti-HSV IgG antibody in patients with HSV encephalitis (Aurelius et al, 1991). In contrast, in patients with VZV vasculopathy, which is usually more protracted, anti-VZV IgG antibody is found in the CSF of all patients, compared to VZV DNA in only $30 \%$ of patients (Nagel et al, 2008). Overall, detection of VZV DNA in VZV meningitis and HSV DNA in HSV encephalitis reflects acute disease compared to chronic VZV vasculopathy when antiVZV IgG antibody is always present and VZV DNA is present far less often. Second, the low level of CSF glucose in the presence of normal serum glucose levels in our patient was equal to the lowest ever reported in a 24-year-old man with thoracic zoster and aseptic meningitis whose CSF on day 5 showed glucose at $28 \mathrm{mg} / \mathrm{dl} ; 4$ days later, CSF glucose was $57 \mathrm{mg} / \mathrm{dl}$ (Wolf, 1974). Surprisingly, even on day 13, when our patient had improved clinically and viral DNA was no longer found in the CSF, glucose levels in CSF remained low.

Hypoglycorrhachia with VZV infection has been reported in zoster meningitis of immunocompetent adults (Echevarria et al, 1987; Moriuchi et al, 1997), even in the absence of rash (Mayo and Booss, 1989) and in children (Jhaveri et al, 2003; Leahy et al, 2008), as confirmed by PCR and serology. Hypoglycorrhachia has also been found in VZV 
meningoencephalitis after ophthalmic distribution zoster (Reimer and Beller, 1981; Norris et $a l, 1970$ ) and in zoster polyneuritis with no rash (Mayo and Booss, 1989).

In the past, VZV was considered to be a rare cause of viral meningitis. A survey of 368 patients with aseptic meningitis admitted to the Los Angeles County General Hospital in 1958 failed to identify VZV as a possible etiologic agent in any of these patients (Lennette et al, 1962), likely due to the techniques used to identify VZV, i.e., inoculation of stool cultures into monkey kidney cells and into 1-day-old mice. VZV isolation from CSF or stool is rare, and VZV is an exclusively human virus that does not produce disease after experimental infection of mice (Wroblewska et al, 1982). More recently, proof that VZV can cause serious neurological disease, often in the absence of rash, has been based on serologic analyses to detect VZVspecific antibodies (Shoji et al, 1976), as well as intracellular antigen in patients with zoster meningoencephalitis, cranial and spinal radiculoneuritis (Peters et al, 1979), and intrathecal production of anti-VZV antibodies (Martinez-Martin et al, 1985; Echevarria et al, 1987). Most recently, combined PCR and antibody testing revealed that VZV causes 5\% to $27 \%$ of all aseptic meningitis (Koskiniemi et al, 2001; Hausfater et al, 2004; Kupila et al, 2006; Frantzidou et al, 2008), which is not altogether surprising because PCR has already shown that VZV causes zoster sine herpete (Gilden et al, 1994), vasculopathy (Gilden et al, 1996), acute (Gilden, 1994) and recurrent (Gilden et al, 2009) myelopathy, acute cerebellar ataxia (Moses et al, 2006; Ratzka et al, 2006), and retinal necrosis (el Azazi et al, 1991; Galindez et al, 1996), all without rash.

Viruses that can cause aseptic meningitis with hypoglycorrhachia include lymphocytic choriomeningitis virus (Jamieson et al, 1986) and mumps virus (Wilfert, 1969), as well as ECHO (Mirani et al, 1973) and Coxsackie (Marier et al, 1975) viruses in children. Now, VZV can be added to this list. PCR analysis, especially in the first week of acute symptoms of meningitis, with or without VZV rash, is essential in accurate diagnosis and treatment.

\section{Acknowledgments}

This work was supported in part by Public Health Service grants AG 006127 and NS 32623 from the National Institutes of Health. The authors thank Cathy Allen for preparing the manuscript.

\section{References}

Aurelius E, Johansson B, Skoldenberg B, Staland A, Forsgren M. Rapid diagnosis of herpes simplex encephalitis by nested polymerase chain reaction assay of cerebrospinal fluid. Lancet 1991;337:189192. [PubMed: 1670839]

Echevarria JM, Martinez-Martin P, Tellez A, de Ory F, Rapun JL, Bernal A, Estevez E, Najera R. Aseptic meningitis due to Varicella-Zoster virus: serum antibody levels and local synthesis of specific IgG, IgM and IgA. J Infect Dis 1987;155:959-967. [PubMed: 3031175]

el Azazi M, Samuelsson A, Linde A, Forsgren M. Intrathecal antibody production against viruses of the herpesvirus family in acute retinal necrosis syndrome. Am J Ophthalmol 1991;112:76-82. [PubMed: 1652896]

Frantzidou F, Kamaria F, Dumaidi K, Skoura L, Antoniadis A, Papa A. Aseptic meningitis and encephalitis because of herpesviruses and enteroviruses in an immunocompetent adult population. Eur J Neurol 2008;15:995-997. [PubMed: 18637823]

Galindez OA, Sabates NR, Whitacre MM, Sabates FN. Rapidly progressive outer retinal necrosis caused by varicella zoster virus in a patient infected with human immunodeficiency virus. Clin Infect Dis 1996;22:149-151. [PubMed: 8824984]

Gilden DH. Herpes zoster with postherpetic neuralgia-persisting pain and frustration. N Engl J Med 1994;330:932-934. [PubMed: 8114868] 
Gilden DH, Kleinschmidt-DeMasters BK, Wellish M, Hedley-Whyte ET, Rentier B, Mahalingam R. Varicella zoster virus, a cause of waxing and waning vasculitis: the New England Journal of Medicine case 5-1995 revisited. Neurology 1996;47:1441-1446. [PubMed: 8960724]

Gilden D, Nagel MA, Ransohoff RM, Cohrs RJ, Mahalingam R, Tanabe JL. Recurrent varicella zoster virus myelopathy. J Neurol Sci. 2009in press

Gilden DH, Wright RR, Schneck SA, Gwaltney JM Jr, Mahalingam R. Zoster sine herpete, a clinical variant. Ann Neurol 1994;35:530-533. [PubMed: 8179298]

Hausfater P, Fillet AM, Rozenberg F, Arthaud M, Trystram D, Huraux JM, Lebon P, Riou B. Prevalence of viral infection markers by polymerase chain reaction amplification and Interferon-alpha measurements among patient undergoing lumbar puncture in an emergency department. J Med Virol 2004;73:137-146. [PubMed: 15042661]

Jamieson DG, Mehta PD, Lavi E. Oligoclonal immunoglobulin bands in cerebrospinal fluid of a patient with lymphocytic choriomeningitis. Ann Neurol 1986;19:386-388. [PubMed: 3707091]

Jhaveri R, Sankar R, Yazdani S, Cherry JD. Varicella-zoster virus: an overlooked cause of aseptic meningitis. Pediatr Infect Dis J 2003;22:96-97. [PubMed: 12553305]

Koskiniemi M, Rantalaiho T, Piiparinen H, Bonsdorff CH, Färkkilä M, Järvinen A, Kinnunen E, Koskiniemi S, Mannonen L, Muttilainen M, Linnavuori K, Porras J, Puolakkainen M, Räihä K, Salonen EM, Ukkonen P, Vaheri A, Valtonen V. Infections of the central nervous system of suspected viral origin: a collaborative study from Finland. J NeuroVirol 2001;7:400-408. [PubMed: 11582512]

Kupila L, Vuorinen T, Vainionpää R, Hukkanen V, Marttila RJ, Kotilainen P. Etiology of aseptic meningitis and encephalitis in an adult population. Neurology 2006;66:75-80. [PubMed: 16401850]

Leahy TR, Webb DW, Hoey H, Butler KM. Varicella zoster virus associated acute aseptic meningitis without exanthem in an immunocompetent 14-year-old boy. Pediatr Infect Dis J 2008;27:362-363. [PubMed: 18316987]

Lennette EH, Magoffin RL, Knouf EG. Viral central nervous system disease. An etiologic study conducted at the Los Angeles County General Hospital. JAMA 1962;179:97-105.

Marier R, Rodriguez W, Chloupek RJ, Brandt CD, Kim HW, Baltimore RS, Parker CL, Artenstein MS. Coxsackievirus B5 infection and aseptic meningitis in neonates and children. Am J Dis Child 1975;129:321-325. [PubMed: 1121962]

Martinez-Martin P, Garcia-Saiz A, Rapun JL, Echevarra JM. Intrathecal synthesis of IgG antibodies to varicella-zoster virus in two cases of acute aseptic meningitis syndrome with no cutaneous lesions. J Med Virol 1985;16:201-209. [PubMed: 2989422]

Mayo DR, Booss J. Varicella zoster-associated neurologic disease without skin lesions. Arch Neurol 1989;46:313-315. [PubMed: 2537615]

Mirani M, Ogra PL, Barron AL. Epidemic of echovirus type 9 infection. Certain clinical and epidemiologic features. N Y State J Med 1973;73:403-406. [PubMed: 4510097]

Moriuchi H, Moriuchi M, Sun CC, Trucksis M. Disseminated cutaneous zoster and aseptic meningitis in a previously healthy patient. J Infect 1997;35:183-185. [PubMed: 9354356]

Moses H, Nagel MA, Gilden DH. Acute cerebellar ataxia in a 41 year old woman. Lancet Neurol 2006;5:984-988. [PubMed: 17052665]

Nagel MA, Cohrs RJ, Mahalingam R, Wellish MC, Forghani B, Schiller A, Safdieh JE, Kamenkovich E, Ostrow LW, Levy M, Greenberg B, Russman AN, Katzan I, Gardner CJ, Hausler M, Nau R, Saraya T, Wada H, Goto H, de Martino M, Ueno M, Brown WD, Terborg C, Gilden DH. The varicella zoster virus vasculopathies. Clinical, CSF imaging, and virologic features. Neurology 2008;70:853-860. [PubMed: 18332343]

Norris FH, Leonards R, Calanchini PR, Calder CD. Herpes-zoster meningoencephalitis. J Infect Dis 1970;122:335-338. [PubMed: 5504713]

Peters AC, Versteeg J, Bots GT, Lindeman J, Smeets RE. Nervous system complications of herpes zoster: immunofluorescent demonstration of varicella-zoster antigen in CSF cells. J Neurol Neurosurg Psychiatry 1979;42:452-457. [PubMed: 221620]

Ratzka P, Schiachetzki JC, Bähr M, Nau R. Varicella zoster virus cerebellitis in a 66-year-old patient without herpes zoster. Lancet 2006;367:182. [PubMed: 16413882]

Reimer LG, Beller LB. CSF in herpes zoster meningoencephalitis. Arch Neurol 1981;38:668. [PubMed: 7295116] 
Shoji H, Koya M, Ogiwara H. Meningitis associated with herpes zoster. Immunofluorescent demonstration of varicella-zoster antigens in CSF cells. J Neurol 1976;213:269-271. [PubMed: 61267]

Wilfert CM. Mumps meningoencephalitis with low cerebrospinal-fluid glucose, prolonged pleocytosis and elevation of protein. N Engl J Med 1969;280:855-858. [PubMed: 5781667]

Wolf SM. Decreased cerebrospinal fluid glucose level in herpes zoster meningitis. Report of a case. Arch Neurol 1974;30:109. [PubMed: 4357129]

Wroblewska Z, Devlin M, Reilly K, van Trieste H, Wellish M, Gilden DH. The production of varicella zoster virus antiserum in laboratory animals. Arch Virol 1982;74:233-238. [PubMed: 6299237] 